\title{
Quadratus Lumborum Blocks in Nephrectomy: A Narrative Review
}

\section{Christopher Little Siamak Rahman}

Department of Anesthesiology and Perioperative Medicine, Ronald Reagan UCLA Medical Center, Los Angeles, CA, USA
Correspondence: Christopher Little Tel + I 9|6-7l|0-6895

Email cjlittle89@gmail.com
This article was published in the following Dove Press journal:

Local and Regional Anesthesia

Abstract: The quadratus lumborum block is a novel truncal block where local anaesthetic is injected adjacent to the quadratus lumborum muscle. It is used for caesarean sections, hip arthroplasty, gynecologic surgery, colectomy, and recently nephrectomy. To date, there are no reviews that outline the efficacy and performance of the quadratus lumborum blocks in patients receiving laparoscopic nephrectomy. The objective of this project was to outline the current available data from both clinical trials along with case series and reports regarding the methods and utility of quadratus lumborum blocks for analgesia in patients receiving nephrectomy. For this literature review, we searched Pubmed, Embase, and Web of Science from their inception until 5/31/2020. Our search terms were as follows: "(nephrectomy OR laparoscopic nephrectomy) AND (QL block OR Quadratus Lumborum block OR QL OR TQL OR Thoracolumbar fascia block)." We analyzed all relevant clinical trials for quality using the Jadad scale. Our search yielded a total of 30 articles, 23 of which we ultimately reviewed for this manuscript. The qualitative sum of these data show that patients receiving quadratus lumborum block for nephrectomies have reduced opioid requirements, reduced pain scores, and improved side-effects relative to other analgesic modalities like epidurals. Based on these findings, we conclude that the quadratus lumborum block is a useful analgesic for patients undergoing nephrectomy.

Keywords: quadratus lumborum block, laparoscopic nephrectomy, regional anesthesiology, peripheral nerve block, postoperative pain

\section{Introduction}

The quadratus lumborum block is a novel truncal block that involves injecting local anesthetic adjacent to the quadratus lumborum muscle. ${ }^{1}$ Based on the different injection sites, there are four types of quadratus lumborum block, namely, lateral quadratus lumborum block, posterior quadratus lumborum block, anterior (or transmuscular) quadratus lumborum block, and intramuscular quadratus lumborum block. Blanco et al originally demonstrated the quadratus lumborum block by injecting LA into the interfascial plane at the anterolateral margin of quadratus lumborum muscle (the lateral quadratus lumborum block) under ultrasound guidance. Later, they modified the point of injection into the posterior wall of quadratus lumborum muscle (the posterior quadratus lumborum block) for postoperative analgesia after cesarean delivery. ${ }^{1}$

The quadratus lumborum block is currently used for a number of operations such as cesarean section, hip hemiarthroplasty, inguinal hernia repair, and nephrectomies. ${ }^{2}$ Even as nephrectomies move away from open procedures, laparoscopic cases are still associated with significant pain with some studies showing no 
difference in pain or opioid demand between the two operations. $^{3,4}$ Multiple studies have demonstrated the quadratus lumborum block's efficacy in reducing opioid requirement and postoperative pain to promote recovery after cesarean section, laparoscopic or laparotomy procedures, and hip surgery. ${ }^{1,5-8}$ For abdominal surgery in particular, the quadratus lumborum block is quickly becoming an appealing alternative to epidural as it lacks central neuraxial block side effects, ${ }^{9}$ but the efficacy of quadratus lumborum block as perioperative pain management in transperitoneal laparoscopic nephrectomy is unclear.

Quadratus lumborum blocks may be particularly useful in nephrectomy as it lacks the adverse effects associated patient controlled analgesia including nausea, vomiting, sedation, and respiratory depression, as well as side effects of patient controlled epidural analgesia such as pruritus hypotension, and urinary retention associated with epidural analgesia. ${ }^{10-13}$ To date, no reviews summarize the utility of quadratus lumborum blocks for nephrectomy patients. Here we will cover types of QLBs in nephrectomy, mechanisms of analgesia, block coverage, role in reducing opioid consumption, efficacy of analgesia, contraindications, and complications.

\section{Methods}

For this literature review, we searched Pubmed, Embase, and Web of Science from their inception until 5/31/2020. Our search terms were as follows: "(nephrectomy OR laparoscopic nephrectomy) AND (QL block OR Quadratus Lumborum block OR QL OR TQL OR Thoracolumbar fascia block)," which yielded a total of 30 articles, 23 of which we ultimately reviewed for this manuscript. For further information on article selection, see the PRISMA diagram in Appendix 1. In our review, we included observational studies or randomized controlled trial that focused on using a quadratus lumborum block for analgesia after nephrectomy. We made no demographic restrictions. All randomized controlled trials included in the study were evaluated using the Jadad Scale. ${ }^{14}$ With the same criteria, we searched Cochrane for ongoing randomized controlled trials but did not include these in our results. We limited all studies to those written in English and on human subjects.

\section{Block Types}

The four types of quadratus lumborum blocks are referred to as anterior, lateral, posterior, and intramuscular quadratus lumborum block. In Figure 1, we show a diagram of the relevant anatomy for these three quadratus lumborum blocks. The anterior quadratus lumborum block involves applying local anesthetic between the quadratus lumborum muscle and the psoas major muscle at the level of the L4 transverse process. $^{15}$

For the lateral quadratus lumborum block local anesthetic is injected on the lateral side of the quadratus lumborum muscle where it contacts the transversalis fascia. ${ }^{16}$ It is typically performed via in-plane approach with needle insertion lateral to the ultrasound transducer moving in an anterior-to-posterior trajectory. ${ }^{16}$

The posterior quadratus lumborum block involves applying LA on the posterior side of the QLM between the QLM and the middle layer of the thoracolumbar fascia, which separates the quadratus lumborum muscle from the paraspinal and latissimus dorsi muscles. ${ }^{1,16}$ Like the lateral quadratus lumborum block, this can be performed using an in-plane technique moving from anterior-to-posterior, but it can also be performed with a posterior-to-anterior needle trajectory. $^{2}$
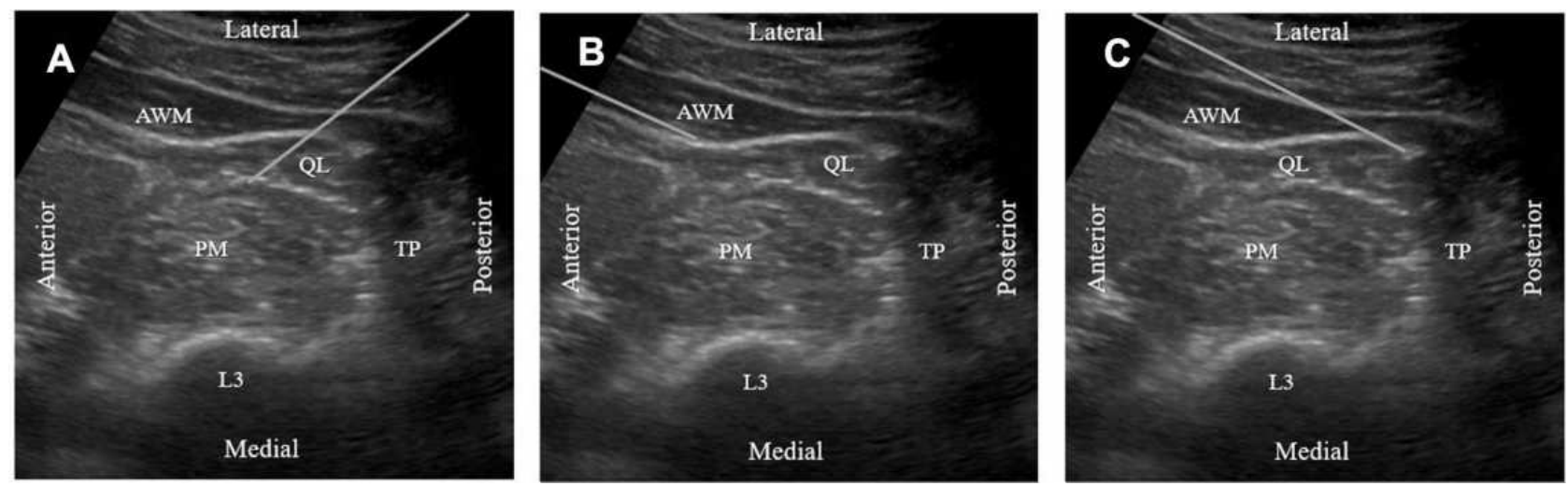

Figure I The relevant anatomy and needle trajectory (gray line) for the three major types of quadratus lumborum blocks. Image (A) shows the anterior (TQL) QLB block with the needle path coming posterior to anterior. Image (B) shows the lateral (QLI) QLB. Image (C) shows the posterior (QL2) QLB.

Abbreviations: AWM, abdominal wall muscles; QL, quadratus lumborum muscle; PM, psoas muscle; TP, transverse process of $L 3$ vertebrae; $L 3$, vertebral body of $L 3$. 
For the intramuscular quadratus lumborum block, local anesthetic is injected directly into the quadratus lumborum muscle. This block is performed by placing the ultrasound transducer slightly cephalad to the iliac crest and advancing the needle in an anterior trajectory until it penetrates the quadratus lumborum muscle. ${ }^{9}$

\section{Mechanism of Action}

Currently, no single mechanism of action provides an explanation for the analgesia of all four quadratus lumborum blocks, and the mechanism for each type of quadratus lumborum block likely varies. Local anesthetic spread along the thoracolumbar fascia and the endothoracic fascia into the paravertebral space may be responsible for some of that analgesia. ${ }^{15}$ Evidence for this mechanism, however, is contradictory with one group showing spread from L1-T5 paravertebral spaces following a transversus abdominis plane block with deposition near the lateral border of the quadratus lumborum muscle, which is in opposition to more recent groups that show contrast injected into the quadratus lumborum plane does not spread to the paravertebral space, though this latter study contained only a single fresh cadaver. ${ }^{17,18}$ While it is still yet to be proven, Akerman et al state a likely mechanism for visceral analgesia in particular results from spread of local anesthetic to the celiac ganglion of sympathetic trunk via splanchnic nerves. ${ }^{15}$

Much work has also been done regarding the mechanism of anterior quadratus lumborum block specifically, with one group showing lateral spread of dye to T11-T12 paravertebral space and no craniocaudal spread when injected at L3 level in fresh cadavers. ${ }^{19}$ In contrast, Adhikary et al showed anterior quadratus lumborum block at L3-L4 had no thoracic paravertebral spread. ${ }^{20}$ Multiple cadaveric studies also support the involvement of roots and upper branches of the lumbar plexus following anterior QLB. ${ }^{19-22}$ Debated continues regarding how much spread to thoracic paravertebral spaces has to do with the efficacy of quadratus lumborum blocks, but it appears the vertebral level of the block influences the extent of cranial spread. ${ }^{2}$ A detailed summary of these studies is shown in Table 1.

The thoracolumbar fascia also has a possible role in the quadratus lumborum block's analgesia. It is a complex connective tissue structure formed from aponeuroses and fascia layers, which connect the anterolateral abdominal wall with the lumbar paravertebral region. Much evidence shows that rather than being a passive scaffold, the thoracolumbar fascia has dense sensory structures like A- and C-fiber nociceptors and mechanoreceptors. Blockade of these nociceptors and mechanoreceptors provides another possible mechanism for the quadratus lumborum block's analgesia. ${ }^{23,24}$ Table 2 outlines our proposed criteria for acute pain following nephrectomy as previously outlined by ACTTION-APS-AAPM Pain Taxonomy (AAAPT). ${ }^{25-29}$ Figure 2 shows the typical trocar placement for laparoscopic nephrectomy.

\section{Opioid Reduction in QLB}

Three major randomized controlled trials all present findings consistent with reduced opioid consumption in patients receiving nephrectomy. ${ }^{30-32} \mathrm{Zhu}$ et al, in a single-center randomized controlled trial of 60 patients, showed 24-hour sufentanil after surgery was 34.1 [9.9] $\mu \mathrm{g}$, compared to 42.1 [11.6] $\mu \mathrm{g}$ in the control group $(\mathrm{p}=0.006) .{ }^{30}$ A second group showed cumulative morphine requirements in nephrectomy patients with QLB was $120 \mathrm{mg}$ compared to $125 \mathrm{mg}$ in the epidural group $(\mathrm{p}=0.703)$. They also reported no difference in time to morphine initiation representing similar postoperative opioid reduction compared to epidurals. ${ }^{31}$ Rahendra et al showed comparable results with their QLB group having 0 mg requirements at 2 hours, and $1 \mathrm{mg}$ on average for the 6 , 12 , and 24 hours timepoints. Their epidural control group had equivalent requirements. ${ }^{32}$ The cumulative data show that QLBs reduce opioid use in patients receiving laparoscopic nephrectomy. These studies are shown in Table 3.

\section{Pain Control Nephrectomy with QLB}

Aditianingsih et al measured numeric rating scale (NRS) for patients with either bilateral anterior quadratus lumborum block or continuous epidural analgesia. They found no difference in static or dynamic NRS scores at 2, 6, 12, and 24 hours post-operatively. ${ }^{31}$ Rahendra et al performed a lateral quadratus lumborum block or continuous epidural on 62 patients total and showed comparable results: Immediate post-op, 2, 6, 12, and 24 hours showed no difference in static or dynamic NRS scores. ${ }^{32}$ While Zhu et al did not measure NRS scores in their study, they demonstrated improved Bruggemann comfort scale scores at 6 and 12 hours for patients in the quadratus lumborum block compared to saline controls, but they found no difference at the 24-hour timepoint. They also showed the number of patients requiring rescue analgesia was lower in the quadratus lumborum block group compared to saline controls. ${ }^{33}$ The case reports and series reviewed in this paper uniformly reported excellent analgesic control following quadratus lumborum block for a 


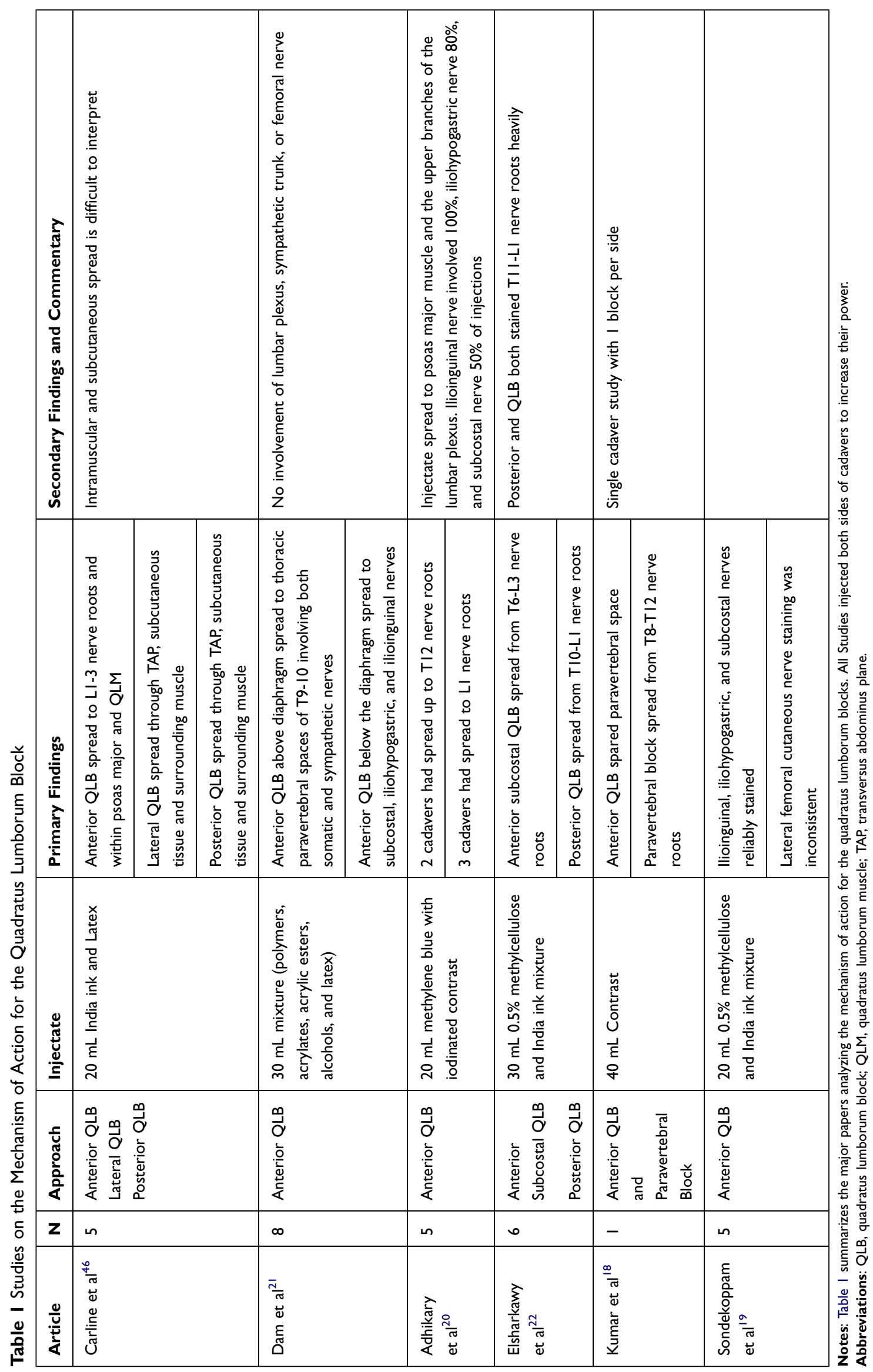


Table 2 AAAPT Criteria for Acute Pain After Nephrectomy

\begin{tabular}{|c|c|}
\hline Dimension & Description \\
\hline \multirow[t]{4}{*}{ I. Core Criteria } & A. The patient has undergone nephrectomy with disruption of the lining of the peritoneum. \\
\hline & B. Pain of some severity $(>0 / 10)$. \\
\hline & C. The pain is primarily in the area of the surgery. \\
\hline & D. Pain onset is immediately following surgery and duration extends to the point of normal healing. \\
\hline $\begin{array}{l}\text { 2. Common } \\
\text { Features }\end{array}$ & $\begin{array}{l}\text { Typically, a single surgical event. Mean NRS scores for laparoscopic donor nephrectomy range from } 4.1 \text { to } 5.1 \text { in the early } \\
\text { postoperative period. }{ }^{26} \text { Pain from laparoscopic nephrectomy comes from port sites, Pfannenstiel retrieval incision, } \\
\text { pneumoperitoneum, and retroperitoneal dissection. }{ }^{27}\end{array}$ \\
\hline $\begin{array}{l}\text { 3. Modulating } \\
\text { Factors }\end{array}$ & $\begin{array}{l}\text { Biological: Comorbidities, surgical complications (infection, hematoma, seroma), anesthetic modalities, preexisting pain, BMI, } \\
\text { age, genetics, pain sensitivity, previous surgery, exercise. Psychological: Anxiety, depression, sleep disturbance, expectations. } \\
\text { Social: Socioeconomic status, education, access to care, context. }\end{array}$ \\
\hline $\begin{array}{l}\text { 4. Functional } \\
\text { Impact }\end{array}$ & $\begin{array}{l}\text { Pain from laparoscopic nephrectomy typically last } 72 \text { hours. }{ }^{28} \text { It is worse during the initial } 4-12 \text { hours. }{ }^{29} \text { Pain from } \\
\text { laparoscopy may delay hospitalization and increase the risk of developing chronic pain. }{ }^{28}\end{array}$ \\
\hline $\begin{array}{l}\text { 5. Putative } \\
\text { Mechanisms }\end{array}$ & $\begin{array}{l}\text { Nociceptive pain may be superficial or deep somatic from port and retrieval incisions, as well as visceral from } \\
\text { pneumoperitoneum and deep dissection. }{ }^{27} \text { Tissue dissection may also result in neuropathic and inflammatory pain. }{ }^{28}\end{array}$ \\
\hline
\end{tabular}

Note: Table 2 outlines our proposed criteria for acute pain following nephrectomy using the criteria set forth by ACTTION-APS-AAPM Pain Taxonomy (AAAPT).

variety of different nephrectomy types. ${ }^{34-41}$ These case studies can be seen in more detail in Table 4. Like with opioid reduction, the randomized controlled trials along with observational studies show the quadratus lumborum blocks are successful in controlling postoperative pain in patients receiving laparoscopic nephrectomy.

\section{Secondary Outcomes}

Aditianingsih et al reported no difference in intraoperative mean arterial pressure, heart rate, or cardiac index between their quadratus lumborum block and continuous epidural group. However, 24 hours postoperatively, the continuous epidural had a significantly lower mean arterial pressure at 72.26 compared to the quadratus lumborum block group at
83.33. ${ }^{31}$ Zhu et al showed quadratus lumborum block patients had a mean arterial pressure of 104 and $101 \mathrm{mmHg}$ at 12 and 24 hours postoperatively compared to Saline Controls which had post-operative mean arterial pressure of 113 and 102 at 12 and 24 hours. ${ }^{30}$ This outcome may represent better control of post-operative pain and sympathetic tone.

Aditianingsih et al also show that most patients with an anterior quadratus lumborum block had loss of sensation from T9-L2 compared to the epidural group that was T8L2. ${ }^{31}$ Zhu et al, performing a subcostal transmuscular quadratus lumborum block, showed sensory blockade from T4-L1. ${ }^{30}$ Additionally, a case series of 6 patients receiving anterior quadratus lumborum block showed

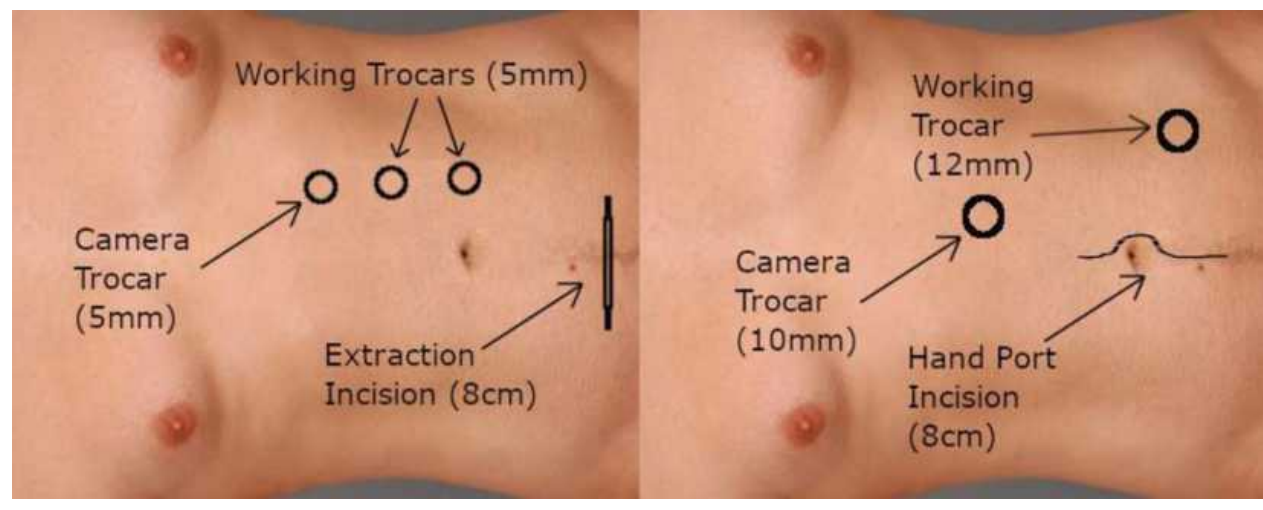

Figure 2 Two common locations for trocar placement and extraction incisions seen in laparoscopic nephrectomies. 
Table 3 Randomized Controlled Trials with Quadratus Lumborum Blocks and Nephrectomy

\begin{tabular}{|c|c|c|c|c|c|c|c|c|}
\hline Article & Year & $\mathbf{N}$ & Surgery & $\begin{array}{l}\text { Quadratus } \\
\text { Lumborum } \\
\text { Block }\end{array}$ & Control & Injectate & $\begin{array}{l}\text { Primary } \\
\text { Outcome }\end{array}$ & Results \\
\hline $\begin{array}{l}\text { Aditianingsih } \\
\text { et } \mathrm{al}^{31}\end{array}$ & 2019 & 62 & $\begin{array}{l}\text { Left } \\
\text { Laparoscopic } \\
\text { donor } \\
\text { nephrectomy } \\
\text { with } \\
\text { Pfannenstiel } \\
\text { incision }\end{array}$ & $\begin{array}{l}\text { Bilateral } \\
\text { Anterior QLB }\end{array}$ & $\begin{array}{l}\text { Continuous epidural } \\
6 \mathrm{~mL} \cdot \mathrm{hr}^{-1} 0.25 \% \\
\text { bupivacaine during } \\
\text { surgery, then } 0.125 \% \\
6 \mathrm{~mL} \cdot \mathrm{hr}^{-1} \text { postop }\end{array}$ & $\begin{array}{l}0.3- \\
0.4 \mathrm{~mL} \cdot \mathrm{Kg}^{-1} \\
0.25 \% \\
\text { bupivacaine } \\
\text { single shot max } \\
\text { volume } 25 \mathrm{~mL}\end{array}$ & $\begin{array}{l}\text { Cumulative } \\
\text { 24-hour } \\
\text { morphine } \\
\text { requirements } \\
\text { and NRS pain } \\
\text { score. }\end{array}$ & $\begin{array}{l}\text { NRS Pain } \\
\text { Scores and } \\
\text { cumulative 24- } \\
\text { hour } \\
\text { morphine use } \\
\text { were } \\
\text { Equivalent. }\end{array}$ \\
\hline Zhu et $\mathrm{al}^{30}$ & 2019 & 60 & $\begin{array}{l}\text { laparoscopic } \\
\text { nephrectomy }\end{array}$ & $\begin{array}{l}\text { Transmuscular } \\
\text { QLB }\end{array}$ & Saline block & $\begin{array}{l}0.4 \mathrm{~mL} \cdot \mathrm{Kg}^{-1} \\
0.3 \% \\
\text { ropivacaine }\end{array}$ & $\begin{array}{l}\text { Sufentanil } \\
\text { PCA } \\
\text { consumption }\end{array}$ & $\begin{array}{l}\text { Sufentanil } \\
\text { lower in QLB } \\
\text { group } \\
\text { compared to } \\
\text { Control }\end{array}$ \\
\hline $\begin{array}{l}\text { Rahendra } \\
\text { et } \mathrm{al}^{32}\end{array}$ & 2019 & 62 & $\begin{array}{l}\text { Laparoscopic } \\
\text { donor } \\
\text { nephrectomy }\end{array}$ & $\begin{array}{l}\text { Bilateral } \\
\text { Anterior QLB } \\
\text { preop and } \\
\text { postop }\end{array}$ & $\begin{array}{l}\text { Continuous epidural } \\
6 \mathrm{~mL} \cdot \mathrm{hr}^{-1} 0.25 \% \text { during } \\
\text { surgery at TII-12 } \\
\text { advanced } 4-6 \mathrm{~cm} \text {. Post op } \\
\text { they got } 0.125 \% \text { at } 6 \\
\mathrm{~mL} \cdot \mathrm{hr}^{-1}\end{array}$ & $\begin{array}{l}\text { bilateral QL } \\
\text { block with } 20 \\
\mathrm{~mL} \text { of } \\
\text { bupivacaine } \\
0.25 \% \text { both } \\
\text { preop and } \\
\text { postop }\end{array}$ & $\begin{array}{l}\text { IL-6 and CRP } \\
\text { measurement }\end{array}$ & $\begin{array}{l}\text { No difference } \\
\text { between IL-6 } \\
\text { or CRP levels }\end{array}$ \\
\hline
\end{tabular}

Note: Table 3 shows a summary of currently completed randomized controlled trials where quadratus lumborum blocks were used in patients receiving nephrectomy with the details surrounding their design and results.

Abbreviation: QLB, quadratus lumborum block.

coverage from T5-L1 in 3 patients and T6-L1 in 3 patients, ${ }^{38}$ indicating some variation in coverage between individual practitioners and between block types but reliable coverage from T7-L1. Zhu et al showed the quadratus lumborum block group had a lower incidence of postoperative nausea and vomiting compared to saline controls. ${ }^{33}$ Aditianingsih et al also showed quadratus lumborum block group compared to epidural controls had a similar incidence of $\mathrm{PONV}^{31}$ Zhu et al also demonstrated earlier return of intestinal function and earlier mobilization in the quadratus lumborum block group compared to saline control. ${ }^{33}$ Finally, Aditianingsih et al showed a shorter duration of urinary catheter use compared to the epidural group. ${ }^{31}$ The combination of these improved secondary outcomes provides a compelling argument for the routine use of quadratus lumborum blocks over epidurals for postoperative pain control in nephrectomy.

\section{Contraindications and}

\section{Complications}

Absolute contraindications are few and are like contraindications for other peripheral nerve blocks including local infection, true allergy to LAs, a bleeding diathesis, and patient refusal. Complications from the quadratus lumborum blocks also parallel those seen in other peripheral nerve blocks. Spread to the lumbar plexus may cause prolonged motor blockade and result in delayed mobilization and discharge. Hypotension has been reported in QLBs and likely results from paravertebral spread of local anesthetic. ${ }^{42}$ Local anesthetic toxicity is possible given the relatively large dose and highly vascular area. ${ }^{43,44}$

The anterior block in particular has potential risk for needle trauma to kidney, liver, and pleura. ${ }^{22,45}$ Given that the quadratus lumborum block is a deep block, there is risk for hematoma development and retroperitoneal spread. The posterior and lateral blocks share a fascial plane with the abdominal branches of the lumbar arteries making hemorrhage possible, but this has not been demonstrated in the literature. Because it is an intramuscular block, risk of infection is likely lower than neuraxial blocks, but this has yet to be studied.

\section{Ongoing Clinical Trials}

There are currently 28 clinical trials registered in the Cochrane database involving the use of quadratus lumborum blocks for 
Table 4 Case Series and Reports with Quadratus Lumborum Blocks and Nephrectomy

\begin{tabular}{|c|c|c|c|c|c|c|}
\hline Article & $\mathbf{N}$ & Surgery & $\begin{array}{l}\text { Timing/ } \\
\text { Indication }\end{array}$ & $\begin{array}{l}\text { Quadratus } \\
\text { Lumborum Block }\end{array}$ & Injectate & Results \\
\hline Graca et $\mathrm{a}^{34}$ & 1 & Partial nephrectomy & Postoperative & Posterior & $\begin{array}{l}\text { Bolus: } 20 \mathrm{~mL} 0.2 \% \\
\text { ropivacaine infusion: } \\
5.2 \mathrm{~mL} \mathrm{hr}^{-1} 0.2 \% \\
\text { ropivacaine for } 48 \\
\text { hours }\end{array}$ & Excellent analgesia \\
\hline Gurkan et $\mathrm{al}^{35}$ & 1 & $\begin{array}{l}\text { Open nephrectomy } \\
\text { and cholecystectomy }\end{array}$ & Perioperative & Anterior & $\begin{array}{l}\text { Bolus: } 20 \mathrm{~mL} \text { of } 0.25 \% \\
\text { bupivacaine }\end{array}$ & $\begin{array}{l}\text { VAS } 0 \text { at } 24 \text { hours. Total } \\
\text { morphine demand } 13 \\
\mathrm{mg} \text {. }\end{array}$ \\
\hline \multirow[t]{2}{*}{ Sindwani et $\mathrm{al}^{36}$} & \multirow[t]{2}{*}{ I } & \multirow{2}{*}{$\begin{array}{l}\text { Laparoscopic radical } \\
\text { nephrectomy for Von } \\
\text { Hipple Lindau Renal } \\
\text { Cell Carcinoma }\end{array}$} & \multirow[t]{2}{*}{ Perioperative } & \multirow{2}{*}{$\begin{array}{l}\text { Anterior Infusion on } \\
\text { operative side } \\
\text { Anterior bolus on } \\
\text { non-operative side }\end{array}$} & $\begin{array}{l}\text { Bolus: } 0.2 \% \text { ropivacaine } \\
20 \mathrm{~mL}\end{array}$ & \multirow{2}{*}{$\begin{array}{l}\text { Excellent analgesia } \\
\text { without opioids; Block } \\
\text { coverage T7-L2 }\end{array}$} \\
\hline & & & & & $\begin{array}{l}\text { Infusion: } 0.2 \% \\
\text { ropivacaine at } 5 \mathrm{~mL} \mathrm{hr}{ }^{-1} \\
\text { for } 48 \text { hours }\end{array}$ & \\
\hline \multirow[t]{2}{*}{ Ueshima et $\mathrm{al}^{37}$} & \multirow[t]{2}{*}{2} & \multirow{2}{*}{$\begin{array}{l}\text { Radical nephrectomy } \\
\text { and laparoscopic } \\
\text { nephrectomy }\end{array}$} & \multirow[t]{2}{*}{ Postoperative } & \multirow[t]{2}{*}{ Anterior subcostal } & $\begin{array}{l}\text { Bolus: } 20 \mathrm{~mL} \text { of } 0.5 \% \\
\text { levobupivacaine }\end{array}$ & \multirow[t]{2}{*}{$\begin{array}{l}\text { Excellent analgesia } \\
\text { without opioids }\end{array}$} \\
\hline & & & & & $\begin{array}{l}\text { Infusion: intermittent } \\
\text { bolus of } 15 \mathrm{~mL} 0.1 \% \\
\text { levobupivacaine }\end{array}$ & \\
\hline Suri et a $\left.\right|^{38}$ & 6 & $\begin{array}{l}\text { Open radical } \\
\text { nephrectomy }\end{array}$ & Postoperative & $\begin{array}{l}\text { Lateral visualized by } \\
\text { surgeon } \\
\text { (Laparoscopic- } \\
\text { guided) }\end{array}$ & $\begin{array}{l}\text { Bolus: } 20 \mathrm{~mL} 0.2 \% \\
\text { ropivacaine Infusion: } \\
0.2 \% \text { infusion } 0.5 \\
\mathrm{~mL} \mathrm{hr}^{-1}\end{array}$ & $\begin{array}{l}\text { Good analgesia with only } \\
\text { I00mg tramadol BID in } \\
\text { all patients; Block } \\
\text { coverage T7-L2 }\end{array}$ \\
\hline \multirow[t]{2}{*}{ Sindwani et $\mathrm{al}^{39}$} & \multirow[t]{2}{*}{5} & \multirow[t]{2}{*}{$\begin{array}{l}\text { Laparoscopic } \\
\text { nephrectomy }\end{array}$} & \multirow[t]{2}{*}{ Postoperative } & \multirow{2}{*}{$\begin{array}{l}\text { Lateral visualized by } \\
\text { surgeon } \\
\text { (Laparoscopic- } \\
\text { guided) }\end{array}$} & $\begin{array}{l}\text { Bolus: } 20 \mathrm{~mL} 0.2 \% \\
\text { ropivacaine }\end{array}$ & \multirow[t]{2}{*}{$\begin{array}{l}\text { Excellent analgesia } \\
\text { without opioids }\end{array}$} \\
\hline & & & & & $\begin{array}{l}\text { Infusion: } 0.2 \% \text { infusion } \\
0.5 \mathrm{~mL} \cdot \mathrm{hr}^{-}\end{array}$ & \\
\hline \multirow[t]{2}{*}{$\begin{array}{l}\text { Chakraborty } \\
\text { et } \mathrm{al}^{34,40}\end{array}$} & \multirow[t]{2}{*}{ I } & \multirow[t]{2}{*}{$\begin{array}{l}\text { Pediatric radical } \\
\text { nephrectomy }\end{array}$} & \multirow[t]{2}{*}{ Postoperative } & \multirow[t]{2}{*}{ Anterior } & $\begin{array}{l}\text { Bolus: } 5 \mathrm{~mL} 0.375 \% \\
\text { levobupivacaine }\end{array}$ & \multirow{2}{*}{$\begin{array}{l}\text { Good analgesia with no } \\
\text { opioids; Block coverage } \\
\text { T7-L2 }\end{array}$} \\
\hline & & & & & $\begin{array}{l}\text { Infusion: } 0.1 \% \\
\text { levobupivacaine } \\
5 \mathrm{~mL} \mathrm{hr}^{-}\end{array}$ & \\
\hline \multirow[t]{2}{*}{$\begin{array}{l}\text { Waruswitharana } \\
\text { et } \mathrm{al}^{4 !}\end{array}$} & \multirow[t]{2}{*}{9} & \multirow[t]{2}{*}{$\begin{array}{l}\text { Open nephrectomy } \\
\text { with } 2 \text { incisions. }\end{array}$} & \multirow[t]{2}{*}{ Perioperative } & \multirow[t]{2}{*}{ Transmuscular } & $\begin{array}{l}\text { Partial nephrectomy: } \\
\text { I00mg levobupivacaine } \\
\text { (ipsilateral only) }\end{array}$ & \multirow[t]{2}{*}{$\begin{array}{l}\text { Mean } 48 \text {-hour morphine } \\
\text { consumption } 62 \mathrm{mg}\end{array}$} \\
\hline & & & & & $\begin{array}{l}\text { Radical nephrectomy: } \\
\text { I50mg levobupivacaine } \\
\text { (bilateral) }\end{array}$ & \\
\hline
\end{tabular}

Notes: Table 4 offers a summary of the available case reports and case series for patients who have received quadratus lumborum block as an analgesic for nephrectomy.

analgesia in nephrectomy patients. Common trials compare quadratus lumborum block to epidural analgesia in nephrectomy, quadratus lumborum block to transversus abdominis plane block in nephrectomy, or quadratus lumborum block to erector spinae block. Finally, several trials are comparing the inflammatory response to nephrectomy in patients with and without quadratus lumborum block. Another interesting trial is currently comparing volume and concentration of local 
anesthetic in quadratus lumborum blocks. In our institution, there is an ongoing trial looking at utility and benefit of injection of liposomal bupivacaine in transmuscular quadratus lumborum block for donor nephrectomy patients. As these trials end, we will have more information regarding the efficacy and ideal use of the quadratus lumborum block in nephrectomy. There is still a lack of information regarding quadratus lumborum block effectiveness in pediatric nephrectomy, which of the quadratus lumborum blocks is most effective in nephrectomy, and how effective quadratus lumborum block is in treating visceral pain.

\section{Conclusion}

Although the studies surrounding quadratus lumborum block in nephrectomy are still ongoing, the existing data support using quadratus lumborum blocks for postoperative pain control and opioid reduction in patients receiving open or laparoscopic nephrectomy. Compared to epidural analgesia, quadratus lumborum blocks appear to provide equivalent analgesia with less hemodynamic compromise, and less postoperative nausea and vomiting, with a shorter duration of urinary catheterization analgesia, time to mobilization and return of bowel function.

\section{Disclosure}

The authors report no conflicts of interest in this work.

\section{References}

1. Blanco RAT, Riad W, Shetty N. Quadratus lumborum block versus transversus abdominis plane block for postoperative pain after cesarean delivery: a randomized controlled trial. Reg Anesth Pain Med. 2016;41(6):757-762. doi:10.1097/AAP.0000000000000495

2. Elsharkawy H, El-Boghdadly K, Barrington M. Quadratus lumborum block: anatomical concepts, mechanisms, and techniques. Anesthesiology. 2019;130(2):322-335. doi:10.1097/ALN.0000000000002524

3. Ergün MBA, van der Jagt MF, Langenhuijsen JF, et al. Components of pain assessment after laparoscopic donor nephrectomy. Acta Anaesthesiol Scand. 2014;58(2):219-222. doi:10.1111/aas.12236

4. Alper IYE. Comparison of acute and chronic pain after open nephrectomy versus laparoscopic nephrectomy: a prospective clinical trial. Medicine (Baltimore). 2016;95(16):e3433. doi:10.1097/ MD.0000000000003433

5. Ishio JKN, Kido H, Minami T. Evaluation of ultrasound-guided posterior quadratus lumborum block for postoperative analgesia after laparoscopic gynecologic surgery. J Clin Anesth. 2017;41:1-4. doi:10.1016/j. jclinane.2017.05.015

6. Murouchi TIS, Yamakage M. Quadratus lumborum block: analgesic effects and chronological ropivacaine concentrations after laparoscopic surgery. Reg Anesth Pain Med. 2016;41(2):146-150. doi:10.1097/ AAP.0000000000000349

7. McCrum CLB-DB, Shin JJ, Wright VJ. Quadratus lumborum block provides improve immediate postoperative analgesia and decreased opioid use compared with a multimodal pain regimen following hip arthroscopy. Hip Preserv Surg. 2018;5(3):233-239. doi:10.1093/jhps/ hny024
8. Corso RM, Piraccini E, Sorbello M, Bellantonio D, Tedesco M. Ultrasound-guided transmuscular quadratus lumborum block for perioperative analgesia in open nephrectomy. Minerva Anestesiol. 2017;83(12):1334-1335. doi:10.23736/S0375-9393.17.12167-X

9. Ueshima $\mathrm{HOH}$, Lin J. Ultrasound-guided quadratus lumborum block: an updated review of anatomy and techniques. Biomed Res Int. 2017. doi: $10.1155 / 2017 / 2752876$

10. Sahajananda H, Jyothi P. Renal transplantation with and without epidural analgesia. Indian J Anesth. 2006;50(3):187-192.

11. Förster JG, Rosenberg PH, Niemi TT. Continuous spinal microcatheter (28 gauge) technique for arterial bypass surgery of the lower extremities and comparison of ropivacaine with or without morphine for postoperative analgesia. Br J Anaesth. 2006;97(3):393-400. doi:10.1093/bja/ael147

12. Morgan PJ, Halpern SH, Tarshis J. The effects of an increase of central blood volume before spinal anesthesia for cesarean delivery: a qualitative systematic review. Anesth Analg. 2001;92(4):997-1005. doi:10.1097/00000539-200104000-00036

13. Darrah DM, Griebling TL, Silverstein JH. Postoperative urinary retention. Anesthesiol Clin. 2009;27(3):465-484. (). doi:10.1016/j. anclin.2009.07.010

14. Jadad AR, Moore RA, Carroll D, et al. Assessing the quality of reports of randomized clinical trials: is blinding necessary? Control Clin Trials. 1996;17(1):1-12. doi:10.1016/0197-2456(95)00134-4

15. Akerman M, Pejčić N, Veličković I. A review of the quadratus lumborum block and ERAS. Front Med (Lausanne). 2018;5:44. doi:10.3389/fmed.2018.00044

16. Blanco R, Ansari T, Girgis E. Quadratus lumborum block for postoperative pain after caesarean section: a randomised controlled trial. Eur J Anaesthesiol. 2015;32(11):812-818. doi:10.1097/ EJA.0000000000000299

17. Carney J, Finnerty O, Rauf J, Bergin D, Laffey JG, Mc Donnell JG. Studies on the spread of local anaesthetic solution in transversus abdominis plane blocks. Anaesthesia. 2011;66(11):1023-1030. doi:10.1111/j.1365-2044.2011.06855.x

18. Kumar A, Sadeghi N, Wahal C, Gadsden J, Grant SA. Quadratus lumborum spares paravertebral space in fresh cadaver injection. Anesth Analg. 2017;125(2):708-709. doi:10.1213/ANE.0000000000002245

19. Sondekoppam RV, Ip V, Johnston DF, et al. Ultrasound-guided lateral-medial transmuscular quadratus lumborum block for analgesia following anterior iliac crest bone graft harvesting: a clinical and anatomical study. Can J Anaesth. 2018;65(2):178-187. doi:10.1007/ s12630-017-1021-y

20. Adhikary SD, El-Boghdadly K, Nasralah Z, Sarwani N, Nixon AM, Chin KJ. A radiologic and anatomic assessment of injectate spread following transmuscular quadratus lumborum block in cadavers. Anaesthesia. 2017;72(1):73-79. doi:10.1111/anae.13647

21. Dam M, Moriggl B, Hansen CK, Hoermann R, Bendtsen TF, Børglum J. The pathway of injectate spread with the transmuscular quadratus lumborum block: a cadaver study. Anesth Analg. 2017;125 (1):303-312. doi:10.1213/ANE.0000000000001922

22. Elsharkawy H, El-Boghdadly K, Kolli S, et al. Injectate spread following anterior sub-costal and posterior approaches to the quadratus lumborum block: a comparative cadaveric study. Eur J Anaesthesiol. 2017;34(9):587-595. doi:10.1097/EJA.0000000000000680

23. Yahia L, Rhalmi S, Newman N, Isler M. Sensory innervation of human thoracolumbar fascia. An immunohistochemical study. Acta Orthop Scand. 1992;63(2):195-197. doi:10.3109/17453679209154822

24. Benetazzo L, Bizzego A, De Caro R, Frigo G, Guidolin D, Stecco C. $3 \mathrm{D}$ reconstruction of the crural and thoracolumbar fasciae. Surg Radiol Anat. 2011;33(10):855-862. doi:10.1007/s00276-010-0757-7

25. Albers KI, van Helden EV, Dahan A, et al. Early postoperative pain after laparoscopic donor nephrectomy predicts 30 -day postoperative infectious complications: a pooled analysis of randomized controlled trials. Pain. 2020;161(7):1565-1570. doi:10.1097/j.pain.00000 00000001842 
26. Mathuram Thiyagarajan U, Bagul A, Nicholson ML. Pain management in laparoscopic donor nephrectomy: a review. Pain Res Treat. 2012;2012:201852. doi:10.1155/2012/201852

27. Sjövall S, Kokki M, Kokki H. Laparoscopic surgery: a narrative review of pharmacotherapy in pain management. Drugs. 2015;75 (16):1867-1889.

28. Ekstein P, Szold A, Sagie B, Werbin N, Klausner JM, Weinbroum AA. Laparoscopic surgery may be associated with severe pain and high analgesia requirements in the immediate postoperative period. Ann Surg. 2006;243(1):41-46. doi:10.1097/01. sla.0000193806.81428.6f

29. Bisgaard T, Kehlet H, Rosenberg J. Pain and convalescence after laparoscopic cholecystectomy. Eur J Surg. 2001;167(2):84-96. doi:10.1080/110241501750070510

30. Zhu M, Qi Y, He H, Lou J, Pei Q, Mei Y. Analgesic effect of the ultrasound-guided subcostal approach to transmuscular quadratus lumborum block in patients undergoing laparoscopic nephrectomy: a randomized controlled trial. BMC Anesthesiol. 2019;19(1):154. doi:10.1186/s12871-019-0825-4

31. Aditianingsih D, Pryambodho AN, Tantri AR, Mochtar CA. A randomized controlled trial on analgesic effect of repeated Quadratus Lumborum block versus continuous epidural analgesia following laparoscopic nephrectomy. BMC Anesthesiol. 2019;19(1):221. doi:10.1186/s12871-019-0891-7

32. Rahendra R, Pryambodho P, Aditianingsih D, Sukmono RB, Tantri A, Melati AC. Comparison of IL- 6 and CRP concentration between quadratus lumborum and epidural blockade among living kidney donors: a randomized controlled trial. Anesth Pain Med. 2019;9(2): e91527. doi:10.5812/aapm.91527

33. Zhu Q, Li L, Yang Z, et al. Ultrasound guided continuous Quadratus Lumborum block hastened recovery in patients undergoing open liver resection: a randomized controlled, open-label trial. $B M C$ Anesthesiol. 2019;19(1):23. doi:10.1186/s12871-019-0692-Z

34. Graça R, Miguelez P, Cardoso JM, et al. [Continuous quadratus lumborum type II block in partial nephrectomy]. Rev Bras Anestesiol. 2018;68(6):653-656. Turkish. doi:10.1016/j. bjan.2018.03.001

35. Gürkan Y, Yörükoğlu HU, Ulugöl H, Kuş A. [Quadratus lumborum block for both cholecystectomy and right-sided nephrectomy]. Agri. 2019;31(3):153-154. Turkish. doi:10.5505/agri.2017.24392
36. Sindwani G, Sahu S, Suri A, Saeed Z. Bilateral quadratus lumborum block for postoperative analgesia in a Von Hippel-Lindau syndrome patient undergoing laparoscopic radical nephrectomy. Saudi J Anaesth. 2017;11(4):513-514. doi:10.4103/sja.SJA 263_17

37. Ueshima H, Otake H. Clinical experiences of unilateral anterior subcostal quadratus lumborum block for a nephrectomy. J Clin Anesth. 2018;44:120. doi:10.1016/j.jclinane.2017.11.031

38. Suri A, Sindwani G, Sahu S, Gupta N, Sureka S. Surgeon assisted quadratus lumborum block - 'Gaurav-Aditi' technique case series. $J$ Clin Anesth. 2017;43:48-49. doi:10.1016/j.jclinane.2017.09.012

39. Sindwani G, Suri A, Shrivastava D, Sureka S. Laparoscopic guided continuous type 1 quadratus lumborum block - "Sindwani technique with case series". J Clin Anesth. 2017;42:93-94. doi:10.1016/j. jclinane.2017.08.023

40. Chakraborty A, Goswami J, Patro V. Ultrasound-guided continuous quadratus lumborum block for postoperative analgesia in a pediatric patient. A a Case Rep. 2015;4(3):34-36. doi:10.1213/ XAA.0000000000000090

41. Warusawitharana C, Basar S, Jackson BL, Niraj G. Ultrasound guided continuous transmuscular quadratus lumborum analgesia for open renal surgery: a case series. J Clin Anesth. 2017;42:100-101. doi:10.1016/j.jclinane.2017.08.025

42. Sá M, Cardoso JM, Reis H, et al. [Quadratus lumborum block: are we aware of its side effects? A report of 2 cases]. Rev Bras Anestesiol. 2018;68(4):396-399. Portuguese. doi:10.1016/j.bjan.2017.04.023

43. Gitman M, Barrington MJ. Local anesthetic systemic toxicity: a review of recent case reports and registries. Reg Anesth Pain Med. 2018;43(2):124-130. doi:10.1097/AAP.0000000000000721

44. El-Boghdadly K, Chin KJ. Local anesthetic systemic toxicity: continuing professional development. Can J Anaesth. 2016;63(3):330349. doi:10.1007/s12630-015-0564-z

45. Ahiskalioglu A, Yayik AM, Aydin ME, Ahiskalioglu EO, Caglar O. Incidental hepatomegaly during quadratus lumborum block in pediatric patient. J Clin Anesth. 2019;54:112-113.

46. Carline L, McLeod GA, Lamb C. A cadaver study comparing spread of dye and nerve involvement after three different quadratus lumborum blocks. Br J Anaesth. 2016;117(3):387-394. doi:10.1093/bja/ aew224
Local and Regional Anesthesia

\section{Publish your work in this journal}

Local and Regional Anesthesia is an international, peer-reviewed, open access journal publishing on the development, pharmacology, delivery and targeting and clinical use of local and regional anesthetics and analgesics. The journal welcomes submitted papers covering original research, basic science, clinical studies, reviews \& evaluations, guidelines, expert opinion and commentary, case reports and extended reports. The manuscript management system is completely online and includes a very quick and fair peer-review system, which is all easy to use. Visit http://www.dovepress.com/testimonials. php to read real quotes from published authors. 